\title{
Report
}

\section{Field trip in the Thar Desert}

\author{
Jolanta Czerniawska ${ }^{1 *}$, Jiri Chlachula1,2 \\ 'Institute of Geoecology and Geoinformation, Adam Mickiewicz University in Poznań, Poland, *jolczer@amu.edu.pl \\ ${ }^{2}$ Laboratory for Palaeoecology, Tomas Bata University in Zlin, Czech Republic
}

\begin{abstract}
The Thar Desert is a part of the arid zone of north-western India. The past geomorphic processes on its territory triggered by orogenesis and climate change generated a diversity of landforms, including structural (volcanic dykes, orogenic ridges, hamadas), denudational (pediplains, pediments, desert pavements), fluvial (alluvial terraces, gullies, gravelly plains of ancient palaeochannels), lacustrine and deltaic, transgressive marine, aeolian (sand dunes) and anthropogenic (such as fields, rock mines and playas, salinas). Ongoing desertification, mass sediment transfer and ground salinization poses major threats to the local ecosystems and occupation habitats. These negative effects are responded to by new agricultural strategies contributing to the economic sustainability of the western Rajasthan.
\end{abstract}

Key Words: geomorphology processes, geosites, weathering, Thar Desert

The cognitive field trip B8 to the Thar Desert, NW India (Fig. 1A), became a part of the $9^{\text {th }}$ International Conference on Geomorphology in New Delhi (November 6-11, 2017). The five-day study excur-

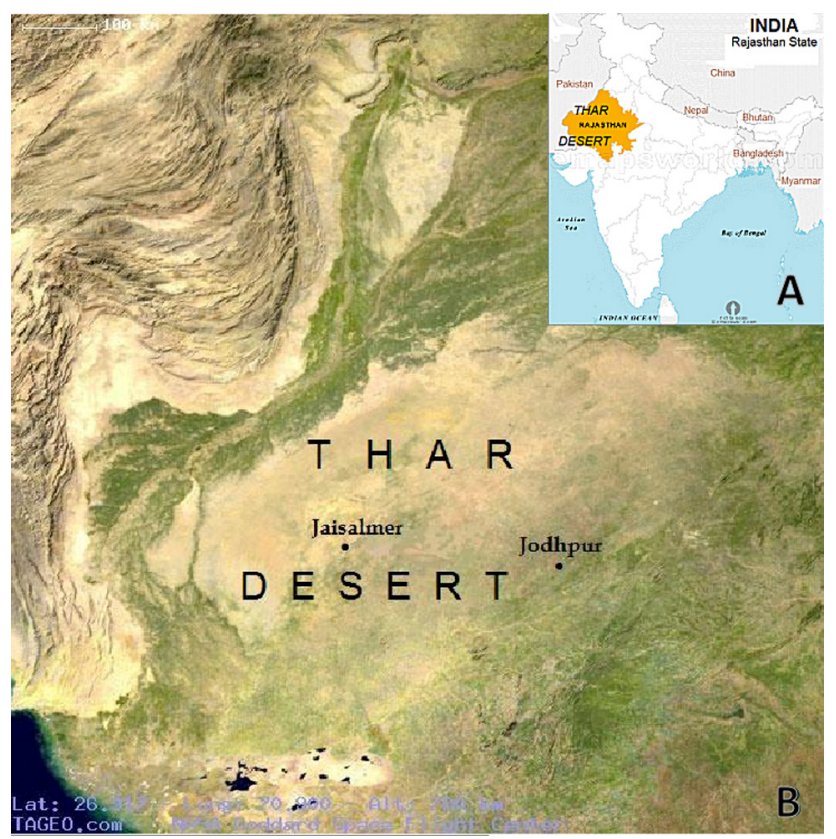

Fig. 1. A. Geographical location of Rajasthan, NW India. B. Satellite image of the Thar Desert, being a part of the arid zone of northwestern India and eastern Pakistan sion was participated by eighteen geomorphologists from twelve countries: Argentina, Australia, Canada, Czech Republic, France, Great Britain, India, Israel, Italy, Japan, Poland, Romania and Slovakia (Fig. 2). The trip was organized and guided by Dr Pratap C. Moharana (Central Arid Zone Research Institute, Jodhpur, Moharana 2017a), and assisted by Ms. Mayuri Mishra (Thomas Cook India Limited, New Delhi).

The aim of the trip, which took place in the Rajasthan State, was to get a first-hand experience and knowledge on the landscape (relief and biotic) diversity in the Thar Desert area in terms of the regional geological history in addition to the cultural evolution, the past and present environmental adaptations of the local people as well as the topical ecology issues linked to the present sustainable development of this arid zone of NW India. In the process, some field geo-data, detailing palaeoenvironmental change in linkage with the initial peopling and palaeocology of this territory were collected.

The field trip started in Jodhpur, the capital of Rajasthan located in the geographic centre of Rajasthan (Fig. 1B). The first stop was in the Central Arid Zone Research Institute $^{1}$ (CAZRI) established in 1952 as the Desert Afforestation Research Station under support of the Australian government. Its main goal was

\footnotetext{
http://www.cazri.res.in/
} 


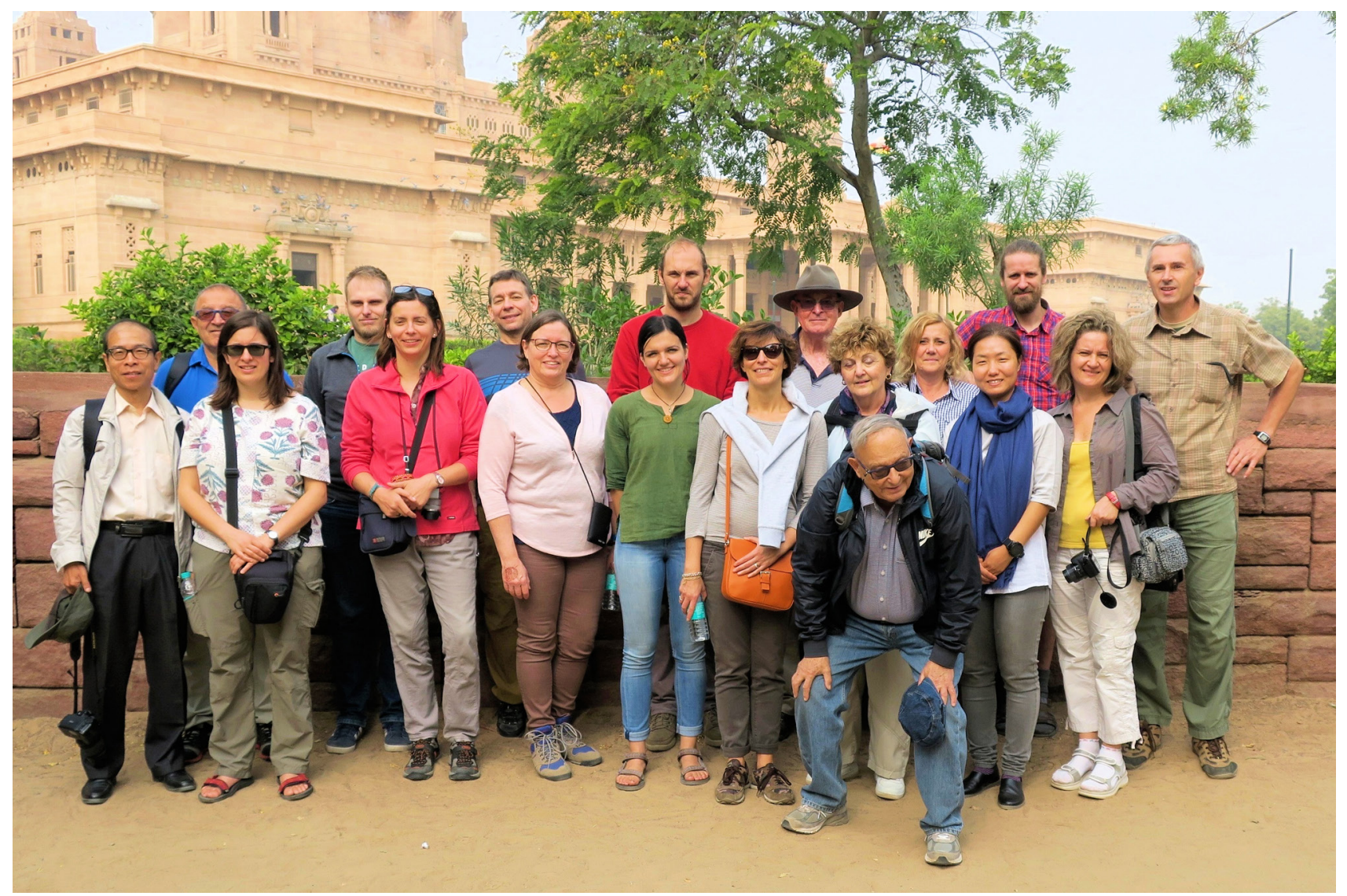

Fig. 2. Participants of the Thar Desert geomorphology field trip in front of the Umaid Bhawan Palace, Jodhpur

sand dune stabilisation in the Thar Desert area and protection of agricultural plantations against progressing desertification of the plain. At present, the CAZRI has five Regional Research Stations and three agricultural technology research centres focusing on cultivation of drought-resistant alimentary and industrial plants. Furthermore, the institute manages five experimental field sectors monitoring the stability of the regional vegetation cover and actual feedback of ongoing climate change. The CAZRI, as the main governmental organization of its kind in India, carries out assessment, monitoring and management of natural resources of the West Indian arid zone in respect to the climate- and human-induced environmental shifts affecting the quality of life of the local peoples. Finally, its major strategic aim is implementation of modern approaches and innovative techniques enhancing productivity of the Thar Desert farmlands in view to the steadily rising local demography. The research institution has developed several need-based and cost-effective technologies aimed at establishment of countryside-protective plantations, wind erosion control, sand dune stabilisation, artificial watershed and water retention reservoir establishment, wasteland mitigation, desert land farming systems and some other alternate land use strategies reflecting the regional natural conditions and socio-economic needs.
Rajasthan is world-famous for its unique cultural heritage with many exceptional historical monuments, some registered in the list of UNESCO, such as the Mehranagarh Fort in Jodhpur and the Jaisalmer Fort representing the stone castles of the local rulers, both being a part of the field trip programme. The former was built in 1459 by Rao Jodha Raja, the governor of Mandore, the present Rajasthan. The latter fort (established in 1156 AD) represented the political centre of the western Thar area during the $12-19^{\text {th }}$ centuries with a spectacular royal palace and several Jain religion temples from finely decorated dark yellow sandstone. These and some other architectonical jewels set-up amid of Thar Desert constitute a supreme human imprint to the original rocky geo-relief and provide witness of artisanal skills and environmental adaptation of the past human generations. A variety of the available and quality raw materials, such as sandstone, limestone and marble, was used for construction taking advantage of the pre-disposed strategic locations of the rocky hills overlooking the surrounding landscape. In essence, the historical Rajasthan, as the most colourful state of India, offers an unsurpassed unity of the Thar Desert natural beauty and the endeavour of its inhabitants over the past centuries and millennia.

By leaving Jodhpur, the trip was heading westwards to the eastern border of Pakistan through a 
disparate landscape with a variety of unconsolidated sandy-gravelly as well as solid rocky terrains, with several stops during the ca. $500 \mathrm{~km}$ long route over 3 days in each direction. Passing through the Agolai, Balesar, Dechu, Pokaran and Chandan cities, spectacular views of parabolic sand dunes, saline playas, prominent hamadas, pediments, gravelly pavements and undulating sandy plains were seen on the way. Impressive relict relief forms testify to the geological complexity of the passing-through geographic area. Except for the geological history linked to both orogenic and climate-change related processes, the field trip focused on the currently most topical environmental issues related to the NW Indian Arid Zone natural conservation and socio-economic development. All of these nicely balanced with the stops at the most interesting cultural sites set up in the geomorphological mosaic landscapes of diverse geological ages and preservation.

The field trip went across the two main districts of western Rajasthan-Jodhpur and Jaisalmer. The principal stops, following the planned daily travel schedule, included:

- geological history (lithostratigraphy and biostratigraphy) of the Thar Desert area,

- geomorphic evolution with the principal and most characteristic landforms related to the arid zone (hamadas, cuestas, pediments, pediplain complexes, gravelly pavements, diverse sand dune complexes, including barchan, parabolic, transverse, and linear dunes (Figs 2-4),

- hydrogeology of riverine palaeosites with largescale sheet-flow and channel bed load alluvial formations; the present-day places with possible fluvial action to the local settings under the currently partly increased climate humidity over the Thar Desert region,

- regional surface- and ground-water hydrology systems; historical and present-day atmospheric water retention structures (nadis, khadins) and ir-

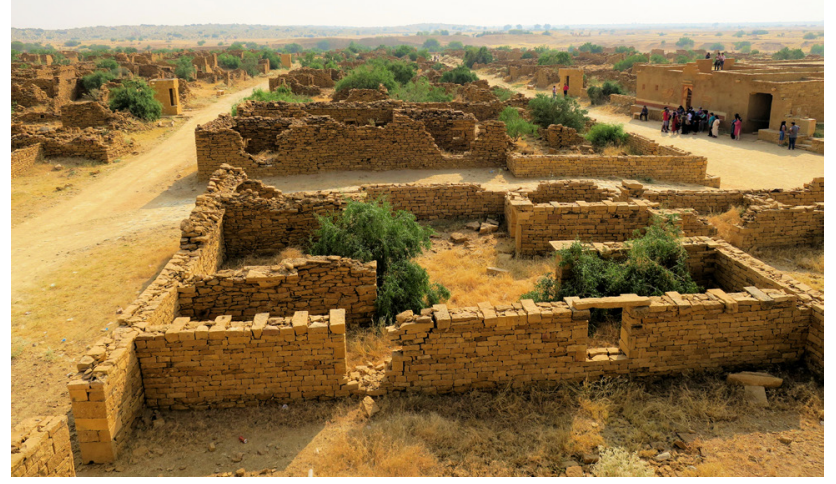

Fig. 3. Ruins of the abandoned early medieval ( $13^{\text {th }}$ century) Kuldhara settlement with a unique street grid system with sandstone-built houses, temples, wells and other structures

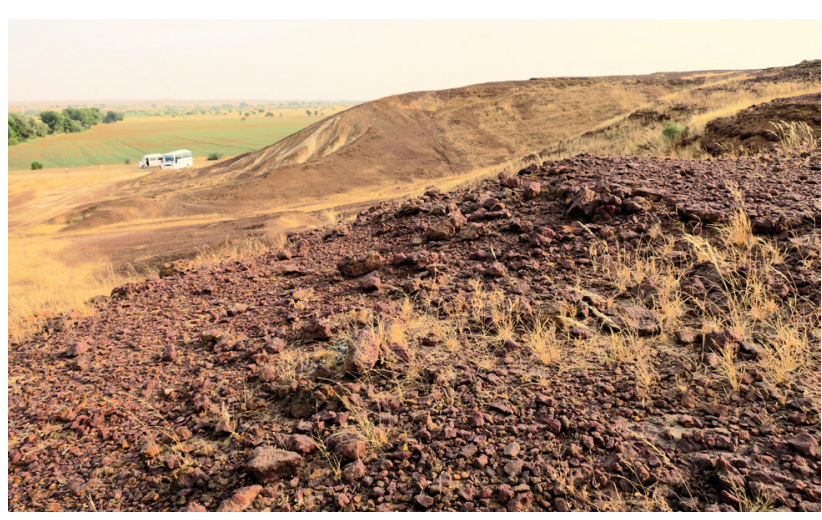

Fig. 4. Escarpments of the Jurassic bedrock-iron per-mineralized sandstone palaeosurface (hamada) at Mokal (40 $\mathrm{km}$ west of Jaisalmer)

rigation channels,

- agricultural land use with cases of anthropogenic pressure to the environment and remediation (traditional and innovative crop cultivation, desert pastoralism and arid-zone vegetation overgrazing; stabilization of dunes through artificial tree plantation, etc.),

- saline landscape with playas, saline depressions (ranns), salt-extraction facilities,

- (pre-)historical and modern industrial exploitation of the geological raw materials (limestone, marble and sandstone mines),

- biotically significant locations and geoecosystems with unique flora and fauna,

- ancient settlements, geoarchaeological sites and cultural monuments (Fig. 3).

The geomorphology focus was on the landforms and the geosites related to past and present relief development as well as modern human influence to the environment. The study field trip included visits of rocky and sandy desert (Jaisalmer), rocky/gravely pediment near the Agolai, Damodara and Mokal towns. At the latter site a flat, strongly weathered surface of low-elevation pediment hills of the exposed Mesozoic (Jurassic/Triassic) sandstone bedrock is an eloquent example of the extreme denudation processes (Fig. 4). Intensive aeolian deflation marked by exposed gravelly pavement void of fine sedimentary matrix can be seen at Chandan and Bhojka sites (Fig. 5 ). These are underlain by a moderately developed lime concretionary zone as a result of past pedogenic processes under a more humid (pluvial) climate then today.

Dynamic past and present aeolian processes are best-documented by the large parabolic dunes (20$30 \mathrm{~m}$ high) in the area of Shetrawa and Dechu, and a linear dune field with barchans near Kanoi and Sam among other places of the western Thar area (Fig. 6). At Dechu, erosional depressions between single dunes expose gravelly deflation surfaces with minor carbonate (kanker) nodules. The Sam dune field, 


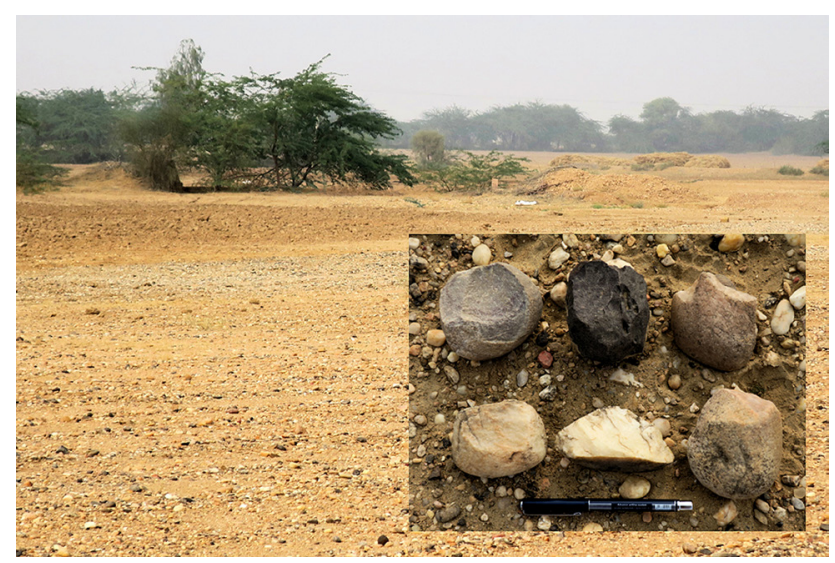

Fig. 5. Pleistocene-age fluvial beds with a wind-sorted sandy-gravelly pavement at Bhojka. Concentrations of Palaeolithic artefacts made on selected clasts of the exposed alluvia point to a sequenced early human occupation of the Thar Desert plain as indicated by a formal (technological) diversity of the lithic industries

forming a chain of barchans, a major of its kind in the Thar Desert, is located ca. $45 \mathrm{~km}$ to the west of Jaisalmer. In 1978, Government of Rajasthan initiated a programme of active dune stabilisation of a part of the longitudinal dune field with a technical expertise of the CAZRI. Successful afforestation of sand dune levee slopes sandy surfaces is well documented at the Shetrawa and Dechu dunes.

Playas or shallow saline depressions interconnected by a system of perennial palaeochannels are found at Khara Bhagotiya, Lawan and Pokaran with seasonally filled clayey-floor ponds amidst the sandy terrain. Modern hydro-environmental facilities aimed at effective agriculturally-oriented water management included khadins (rainwater storage systems) seen near Baramsar about $30 \mathrm{~km}$ from Jaisalmer. Finally, a visit of the sandstone quarry at Balesar underlies the historical tradition of diverse rocky raw material use

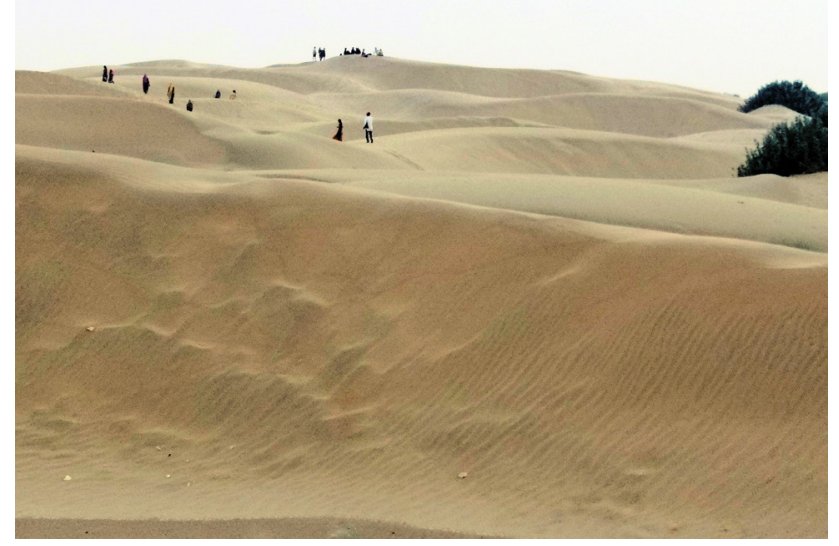

Fig. 6. Linear 20-40 m high sand dunes at Kanoi, SW Thar Desert, with isolated patches of bushy vegetation and wind-deflated depressions exposing an old alluvial gravel pavement in daily life of the Thar Basin people, substituting to a certain respect sparsity of wood.

The Thar Desert fieldtrip more than fulfilled anticipations and generated many perceptions on the past and present geomorphic and geoecology changes associated with the extreme environments of the Thar Desert. Both erosional and accumulation processes are there represented in most eloquent forms, hamadas, the elevated denudation relics of the Mesozoic landscapes, and active Holocene sand dunes fields, respectively. Following the relative orogenic stabilization of the western part of the Indian subcontinent, past climate variations played the decisive role in the topographic restructuring that continues until today.

Findings of the Palaeolithic instruments in the patterned geocontextual settings of the ancient alluvial plains along former palaeochannels and stratigraphically sealed in the Early(?) and Middle Pleistocene stratified sedimentary sequences (Rajaguru et al. 2014, Blinkhorn et al. 2017) point to a very old prehistory of the area. Numerous wind-abraded and iron-mineral stained Old Stone Age lithic instruments and associated waste debris (débitage) indicative of patterned controlled anthropogenic cobble percussion were found during the fieldtrip at several wind-deflated gravel-pavement locations (Agolai, Bhojka I and II) (Fig. 5). The humanly worked lithics ("pebble-tool industry") of a various formal oblique (technological processing and surficial corrosion) provide clear evidence of a sequenced pre-Holocene occupation of the present Thar Desert basin at various, presumably humid stages of the Pleistocene.

The historical and present settlements have locally changed the original landform by construction activities and agrarian practices. A differential modern anthropogenic impact is especially evident in the formerly naturally pristine marginal places of the Thar basin due to the expanding agricultural and pastoral activities, as well as raw material extraction, all predisposing a route building cutting across the desert. These actions linked to the currently progressing peopling of the barren lands pose an immediate impact to the regional natural environment. Desertification and ground water salinization, encountered mainly in the areas of extensive agriculture, are the main ecology threats in the western Rajasthan (Moharana et al. 2016). Protective measures are to be taken to warrant and balance the sustainable socio-economic development of the Thar Desert, $73 \%$ of which are directly exposed to wind erosion (Moharana 2017b). Agro-forestry plays increasing role in the local industry aimed at crops' production as well as the desert land surface stabilisation and desertification control (Singh et al. 1992, Kar et al. 1998, 2007, Rao and Roy 2012).

Equally important is monitoring of seasonal flood effects to geoenvironment and modelling of climate impact to arid land degradation facilitated by 


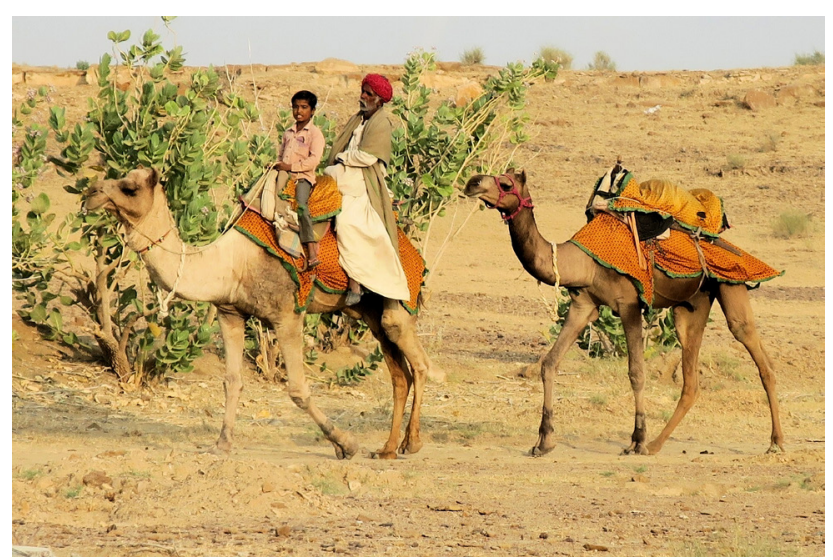

Fig. 7. Nomadic camel herders in the Kanoi sand dune area. Sparse vegetation partly fixing mobilize aeolian deposits in places wind-deflated to the fragmented sandstone bedrock

experimental field studies of the CAZRI, including simulations of fluvial riverine system behaviour after floods and slope wash of sediments during the monsoonal rains (Moharana and Kar 2010). Other landscape ecology issues include geomorphic mapping and landforms analysis in the Thar Desert area in relation to intensified land use and environmental degradation (SAC, 2007, Moharana 2012, Moharana et al. 2013, Raja et al. 2016, Varghese and Singh Naveen 2016). Extensive pastoralism still represents the principal rural economy (Fig. 7).

The specific environmental conditions of the Thar Desert predisposed by unique geomorphic settings and the arid-zone climate regime gave rise to a variety of ecosystems and biotopes reflecting the geographic and climatic zonation of the area with unique floral and faunal communities (e.g. Khan et al. 2003). The Thar National Park $\left(3162 \mathrm{~km}^{2}\right)$ is the largest from the present protected natural areas and biosphere reserves of the desert hosting pristine habitats with endemic wildlife as a pat of the UNESCO World Natural Heritage. The present Thar Desert represents a very dynamic geomorphological region with a great diversity of landforms characteristic of arid subtropical lands. The lack of vegetation and the intensive past and present erosional processes disclose a very ancient geological history with the oldest Pre-Cambrian and Mesozoic bedrock bodies exposed to the present surface as planation pediments or buried by Cenozoic aeolian (sandy dune) deposits amassed in the main sedimentary basins.

The $9^{\text {th }}$ International Geomorphology Conference fieldtrip to the Thar Desert confirmed a major research potential for multidisciplinary geosciences and (palaeo)ecology studies of this still rather poorly explored, but very fascinating territory. The trip uncovered the beauty of this naturally harsh, but friendly and colourful land, and contributed to a better cognizance of the geomorphic processes in the arid zone of NW India.

\section{Acknowledgements}

The authors would like to thank the research fellows from the Central Arid Zone Research Institute (Jodhpur), especially Dr. Pratap C. Moharana among others, and Ms. Mayuri Mishra (Thomas Cook India Ltd., New Delhi) for their professional field trip, organisation and guidance as well as productive discussions on the Thar Desert geological history and cultural heritage.

\section{Selected references}

Allchin B., Goudie A., Hegde K.T.M., 1978. The Prehistory and Palaeogeography of the Great Indian Desert. Academic Press. London.

Attri S.D., Tyagi, A. 2010. Climate Profile of India. India Meteorological Department, New Delhi:1-122.

Bakliwal P.C., Grover A.K., 1988. Signature and migration of Sarasvati River in Thar Desert, western India. Records, Geological Survey of India 116(3-8): 77-86.

Blinkhorna J., Achyuthan H., Ditchfield P., Petraglia M., 2017. Palaeoenvironmental dynamics and Palaeolithic occupation at Katoati, Thar Desert, India. Quaternary Research 87: 298-313.

Deotare B.C., Kajale M.D., Rajaguru S.N., Kusumgar S., Jull A.J.T., Donahue J.D., 2004. Paleoenvironmental history of Bap-Malhar and Kanod playas of western Rajasthan, Thar Desert. Proceedings, Indian Academy of Sciences (Earth \& Planetary Science) 113: 403-425.

Ghose B., Kar A., Husain Z., 1979. The lost courses of the Saraswati River in the Great Indian Desert: New evidence from Landsat imagery. Geographical Journal 145: 446-451.

Ghose B., Singh S., Kar A., 1977. Desertification around the Thar - A geomorphological interpretation. Annals of Arid Zone 16: 290-301.

Heron A.M., 1953. The Geology of Central Rajputana. Memoir, Geological Survey of India 79: 1-389.

Kar A., 1990. The megabarchanoids of the Thar: Their environment, morphology and relationship with longitudinal dunes. Geographical Journal 156: 51-61.

Kar A., 1993a. Aeolian processes and bedforms in the Thar Desert. Journal of Arid Enviroments 25: 83-96.

Kar A., 1993b. Present day geomorphic processes as key to the reconstruction of Quaternary landforms history in the Thar Desert. Journal of the Geological Society of India 41: 513-517.

Kar A., 1999. Neotectonic and climatic controls on drainage evolution in the Thar Desert. In: B.S.Paliwal (ed.), Geological Evolution of North-western India, Scientific Publishers, Jodhpur: 246-259.

Kar A., 2011. Quaternary geomorphic processes and landform developmnent in the Thar Desert of Rajasthan. In: S.Bandyopadhyay, M.Bhattacharji, S.Chaudhuri, D.C.Goswami, S.R.Jog, A.Kar (eds), Landforms, Processes and Environment Management, ACB Publications, Kolkata: 223-254.

Kar A., 2013. Quantification of aeolian bedform and proces parameters in Thar Desert for earth Surface dynamics. Annals of Arid Zone 52 (3\&4):181-207.

Kar A., 2014. The Thar or the Great Indian Sand Desert. In: V.S.Kale (ed.), Landscape and Landforms of India, Springer, Dordrecht: 79-90.

Kar A., Felix C., Rajaguru S.N., Singhvi A.K., 1998. Late Holocene growth and mobility of a transverse dune in the Thar Desert. Journal of Arid Environments 38(2):175-185.

Kar A., Singhvi A.K., Juyal N., Rajaguru S.N., 2004. Late Quaternary aeolian sedimentation history of the Thar Desert. In: 
H.S.Sharma, S.Singh, S.De (eds), Geomorphology and Environment, ACB Publications, Kolkata: 105-122.

Kar A., Moharana P.C., Singh S.K., 2007. Desertification in arid western India. In: K.P.R.Vittal, R.L.Srivastava, N.L.Joshi, A.Kar, V.P.Tewari, S.Kathju (eds), Dryland Ecosystem: Indian Perspective, Central Arid Zone Research Institute, Jodhpur, and Arid Forest Research Institute, Jodhpur: 1-22.

Khan Z., Khan A.A., 2015. A Review on Lithostratigraphy and Biostratigraphy of Jaisalmer basin, western Rajasthan, India. International Research Journal of Earth Science 3(8):37-45.

Khan T.I., Dular A.K., Solomon D.M., 2003. Biodiversity conservation in the Thar Desert; with emphasis on endemic and medical plants. Environmentalist 22(2):137-144.

Mishra D.C., Ravi Kumar D., 2014. Proterozoic orogenic belts and rifting of Indian cratons: Geophysical constraints. Geoscience Frontiers 5: 25-41.

Moharana P. C., 2012. Types, distribution and morphology of aeolian bedforms in canal-irrigated region of arid western Rajasthan. Journal of Indian Geomorphology 1: 1-7.

Moharana P.C., 2017a. B8: Geomorphological Field Guide Book on Thar Desert. A.Kar (ed.), Indian Institute of Geomorphologists, Allahabad: 1-46.

Moharana P.C., 2017b. Identification and characterisation of micro-landform features as clue to recent desertification process in India's arid region. Poster, $9^{\text {th }}$ International Conference on Geomorphology in New Delhi (November 6-11 $1^{\text {th }}, 2017$ ).

Moharana P.C., Gaur M.C., Choudhary C., Chauhan J.S, Rajpurohit R.S., 2013. A system of geomorphological mapping for western Rajasthan with relevance for agricultural land use. Annals of Arid Zone 52:163-180.

Moharana P.C., Kar A., 2010. Quantitative measurement of arid fluvial processes: Results from an upland catchment in Thar Desert. Journal of the Geological Society of India 76: 86-92.

Moharana P.C., Raja P., 2016. Distribution, forms and spatial variability of desert pavements in arid western Rajasthan. Journal of the Geological Society of India 87: 401-410.

Moharana P.C., Santra P., Singh D.V., Kumar S., Goyal R.K., Machiwal D., Yadav O.P., 2016. Erosion processes and desertification in the Thar Desert of India. Proceedings Indian National Science Academy 82: 1117-1140.
Pandey D.K., Sha J., Choudhary S., 2010. Sedimentary cycles in the Callovian-Oxfordian of the Jaisalmer Basin, Rajastan, western India. Volumina Jurassica VIII: 131-162.

Raja P., Srinivas C.V., Hari Prasad K.B.R.R. 2016. Land Surface Processes Simulation Over Thar Desert in Northwest India. Pure and Applied Geophysics 173: 2195.

Rajaguru S.N., Deo S.G., Gaillard, C., 2014. Pleistocene Geoarchaeology of Thar Desert. Annals of Arid Zone 53(2): 63-76.

Rao A.S, Roy M.M, 2012. Weather variability and crop production in arid Rajasthan. CAZRI, Jodhpur, India: 1-70.

SAC [Space Applications Centre], 2007. Desertification and Land Degradation Atlas of India. Space Applications Centre, ISRO. Ahmedabad: 1-74.

SanFilipo J.R., Wnuk Ch., Fariduddin M., Ahmad M., Khan S.A., Mehtab-ur-Rahman, Chandio A.H., Khan R.A., 1992. Potential for the occurrence of thick lignite deposits in Thar Desert and adjacent lower Indus Plain, Singdh Province, Pakistan. Geological Survey of Pakistan and U.S. Geological Survey, Open-File Report 92-576: 1-131.

Singh S., 1982. Types and formation of sand dunes in the Rajasthan Desert. In: H.S.Sharma (ed.), Perspectives in Geomorphology 4, Concept, Delhi: 165-183.

Singh S., Kar A., Joshi D.C., Ram B., Kumar S., Vats P.C., Singh N., Kolarkar A.S, Dhir R.P., 1992. Desertification mapping in western Rajasthan. Annals of Arid Zone 31: 237-246.

Singhvi A.K., Kar A., 2004. The aeolian sedimentation record of the Thar Desert. Proceedings, Indian Academy of Science. Earth and Planetary Science 113:371-401.

Sinha R.S., Malhotra G., Mohanty M., 1998. Geology of Rajasthan. Geological Society of India, Bangalore: 1-278.

Thomas J.V., Kar A., Kailath A.J., Juyal N., Rajaguru S.N., Singhvi A.K., 1999. Late Pleistocene-Holocene history of aeolian accummulations in the Thar Desert, India. Zeitschrift fur Geomorphologie Supplementband 116: 181-194.

Varghese N., Singh N.P., 2016. Linkages between land use changes, desertification and human development in the Thar Desert Region of India. Land Use Policy 51: 18-25.

Wadhawan S., Pankaj K., 2016. Depositional environment in Great Indian Desert using grain size parameters and its chemical characterization. Journal of the Geological Society of India 88(1): $120-121$. 